\title{
Giant hepatic neuroendocrine tumor
}

\section{Seong Hoon Kim, Jangho Park}

National Cancer Center, Goyang-si, Korea

Correspondence to: Seong Hoon Kim, MD, PhD. Center for Organ Transplantation, National Cancer Center, 111 Jungbalsan-ro, Ilsandong-gu, Goyang-si, Gyeonggi-do 410-769, Korea. Email: kshlj@hanmail.net; kshlj@ncc.re.kr.

Submitted Mar 31, 2021. Accepted for publication Apr 22, 2021.

doi: 10.21037/hbsn-21-137

View this article at: https://dx.doi.org/10.21037/hbsn-21-137
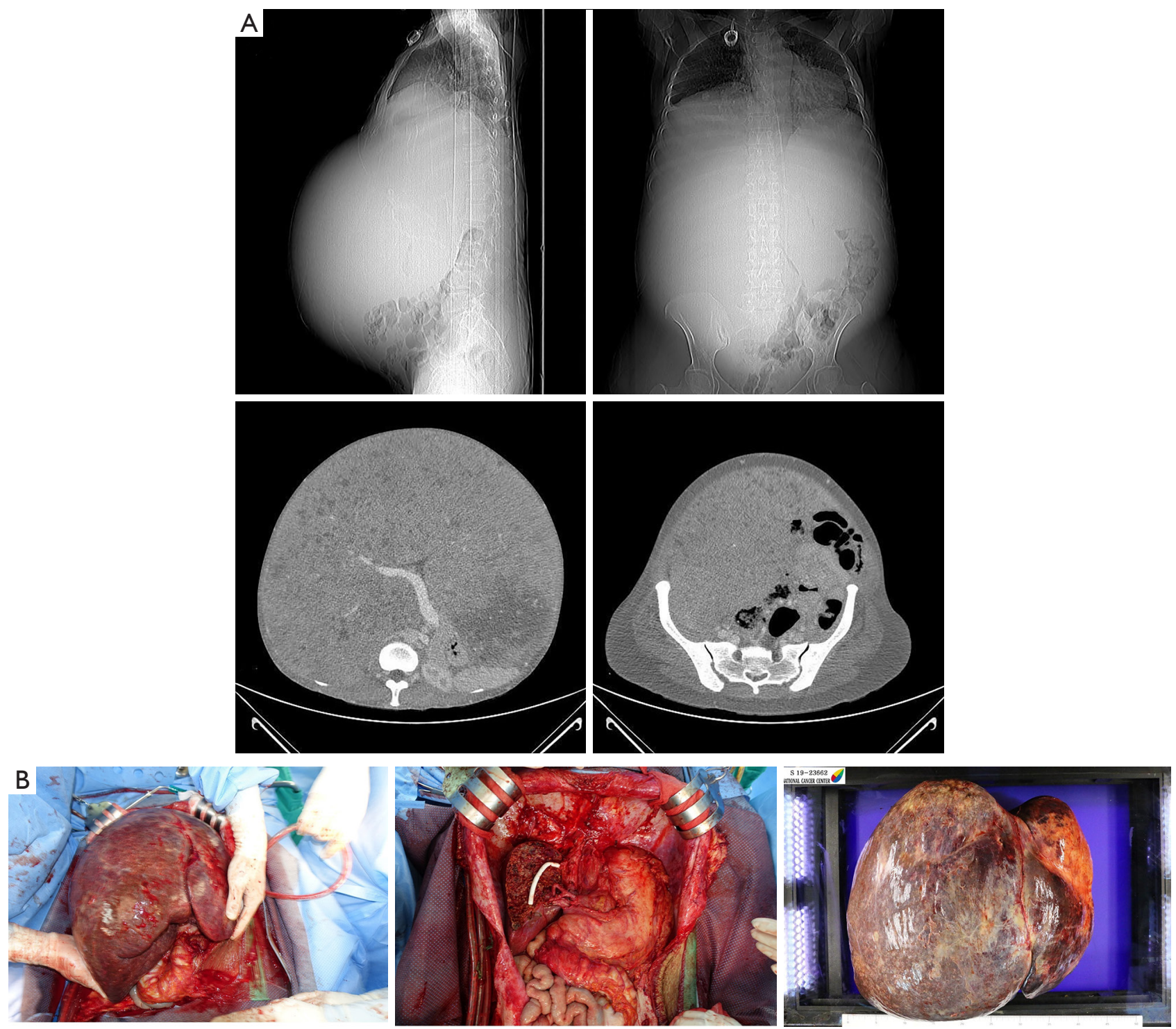
A 47-year-old female was presented with progressive abdominal distension and dyspnea for 2 years. Her height was $152.3 \mathrm{~cm}$ and body weight was $53.9 \mathrm{~kg}$. She was completely confined to bed and could not perform any selfcare tasks. The serum total bilirubin level was $6.4 \mathrm{mg} / \mathrm{dL}$. Radiologic imaging showed multiple hepatic tumors involving a whole liver and compressing inferior vena cava and other organs (Panel A).

One year ago, she was diagnosed neuroendocrine tumor on biopsy, but surgery was judged impossible at other hospitals.

Considering the patient's rapidly deteriorating general condition and no distant metastasis, living donor liver transplantation was performed with a right liver from her 21-year-old daughter. The removed liver weighed $14.5 \mathrm{~kg}$, measuring $43 \mathrm{~cm}$ wide (Panel B).

She was discharged with normal liver function under good general conditions on postoperative day 86 . Unfortunately, she fell down and expired due to cerebral hemorrhage on 11 months after transplantation.

\section{Acknowledgments}

Funding: None.

\section{Footnote}

Provenance and Peer Review: This article was a standard submission to the Hepatobiliary Surgery and Nutrition. The article did not undergo external peer review.

Conflicts of Interest: Both authors have completed the ICMJE uniform disclosure form (available at https://hbsn. amegroups.com/article/view/10.21037/hbsn-21-137/coif). The authors have no conflicts of interest to declare.

Etbical Statement: The authors are accountable for all aspects of the work in ensuring that questions related to the accuracy or integrity of any part of the work are appropriately investigated and resolved. Written informed consent was obtained from the patient for publication of this manuscript and any accompanying images.

Open Access Statement: This is an Open Access article distributed in accordance with the Creative Commons Attribution-NonCommercial-NoDerivs 4.0 International License (CC BY-NC-ND 4.0), which permits the noncommercial replication and distribution of the article with the strict proviso that no changes or edits are made and the original work is properly cited (including links to both the formal publication through the relevant DOI and the license). See: https://creativecommons.org/licenses/by-nc$\mathrm{nd} / 4.0 \%$.
Cite this article as: Kim SH, Park J. Giant hepatic neuroendocrine tumor. HepatoBiliary Surg Nutr 2021;10(5):746-747. doi: 10.21037/hbsn-21-137 